\title{
Effects of Sustainable Home-Yard Food Garden (KRPL) Program: A Case of Banten in Indonesia
}

\author{
Eka Rastiyanto Amrullah ${ }^{1,2}$, Ani Pullaila ${ }^{1,2}$, Akira Ishida ${ }^{1} \&$ Haruka Yamashita $^{1}$ \\ ${ }^{1}$ Graduate School of Agricultural Science, Kobe University, Kobe, Japan \\ ${ }^{2}$ Indonesian Agency for Agricultural Research and Development, Ministry of Agriculture, Indonesia \\ Correspondence: Akira Ishida, Graduate School of Agricultural Science, Kobe University, Kobe, Rokkodai-cho \\ 1-1, Nada, Kobe, Japan. Tel: 81-78-803-5844. E-mail: akira_ishida@people.kobe-u.ac.jp
}

Received: April 6, 2017

doi:10.5539/ass.v13n7p1
Accepted: May 19, $2017 \quad$ Online Published: June 23, 2017

URL: https://doi.org/10.5539/ass.v13n7p1

\begin{abstract}
This study aims to evaluate the effects of an urban and peri-urban agriculture program called Sustainable Home-Yard Food Garden (KRPL, Kawasan Rumah Pangan Lestari) on participants' household income and identify factors affecting the extent to which a participant is actively involved in the program. Many varieties of fresh vegetables, such as chilies, celery, mustard, kai lan (Chinese broccoli), eggplants, tomatoes, cauliflower, lettuce, packoy (Chinese cabbage), cabbage, long beans, and spinach, are harvested from plastic pots, suggesting the program contributes to dietary diversification. In addition, participating in the KRPL program results in cutting back on expenditure on fresh vegetables and/or increasing household income to a certain extent. The estimation results of the OLS regression model using the interview survey data indicate that a KRPL participant who has a larger number of pots and/or grows more varieties of vegetables tends to exhibit the following characteristics: (1) she likes gardening and/or spending time in nature, (2) she is not motivated by a passive reason for participating in the KRPL program, (3) she grows vegetables for the purpose of selling them, (4) the largest proportion of products is sold to someone or given to her friends/neighbors/relatives, and (5) she resides in the more developed northern part of Banten, which is directly connected to the capital city by the Jakarta-Merak toll road.
\end{abstract}

Keywords: Urban and peri-urban agriculture, Indonesia

\section{Introduction}

Food security is an issue of increasing global concern since it can affect national resilience and security both positively and negatively (Hermawan et al., 2014; Opitz et al., 2016). Not only at a national level, but also at an individual level, food security is a critical issue for Indonesia, particularly in light of its pledge to find solutions to "eradicate extreme poverty and hunger" as one of the eight Millennium Development Goals (Hermawan et al., 2014). However, obstacles to achieving this goal include land constraints, increasing demand for food along with rapid population growth, and unprecedented climate change (Bandara \& Cai, 2014; Giovannucci et al., 2012; Meskhia, 2016; Misra, 2014). Among those obstacles, land constraints particularly are tight nowadays, since agricultural lands have been converted to fulfill non-agricultural purposes in response to rapid economic growth in urban and suburban areas (Iqbal \& Sumaryanto, 2007).

While land constraints are a constraint on food security, Hermawan et al. (2014) states that shortages in cultivated land lead people to pursue alternative methods of food production than production on agricultural lands. In order to solve the problem of insufficient land to grow necessary volumes of crops, urban and peri-urban agriculture (UPA) can become an approach to supply food to households and society (Food and Agriculture Organization of the United Nations [FAO], 2011). Under UPA, various kinds of crops and livestock are grown or reared in home gardens, residential areas, and other available unoccupied spaces. UPA has been shown to improve the nutrition status of households (Maxwell et al., 1998) and children (Mwangi, 1995). While UPA can help improve household-level food security, it also offers a route for households to generate supplementary income (Ashebir et al., 2007). A number of researchers support the argument that UPA will be the correct strategy to enable the urban poor in developing countries to obtain better access to food on their own as well as increase their income (Freeman, 1991; Maxwell \& Zziwa, 1992; Maxwell, 1995; Yusuf et al., 2015) (Note 1). 
In Indonesia, the Ministry of Agriculture has promoted a UPA program called the Sustainable Home-Yard Food Garden Scheme (RPL, Rumah Pangan Lestari) and its extended Regional Sustainable Home-Yard Food Garden Scheme (KRPL, Kawasan Rumah Pangan Lestari). RPL aims to optimize land utilization of home-yards only. Under RPL, a house's residents engage in gardening activities in their yards by growing a variety of vegetables, which helps meet the household's demand for foods in the long run. RPL aims to optimize use of spaces within the property, such as front, back, and side yards, the walls, roof, and basement, for food production purposes (Haryanto \& Warsana, 2014). RPL is extended to KRPL when multiple RPL practices are integrated into a larger-scale practice across a community. KRPL aims to optimize land utilization more thoroughly than RPL. KRPL extends space utilization to incorporate fences, community roads, and other public facilities (schools, mosques, etc.), and green open land (Ministry of Agriculture, 2012). Plastic container pots are the standard gear to grow crops in RPL and KRPL.

The Ministry of Agriculture (2012) has defined five objectives for KRPL: (1) sustainably utilizing household space for attaining household food security, (2) diversifying consumed food and nutrient sources from local resources, (3) conservation of genetic resources of food (crops, livestock, and fish), (4) achieving sustainability throughout a village by existence of nurseries, and (5) increasing households' income and social welfare.

While KRPL appears to offer a way for urban and peri-urban households to gain food security and additional income, few researches have discussed the KRPL program's impact on participants' household income, or analyzed the types of people or households who are more actively involved in the program. Therefore, this study aims to evaluate the impact on household income and identify personal attributes, perceptual factors, and geographic factors affecting participation in the KRPL program.

\section{KRPL in Indonesia}

In Indonesia, RPL was initially introduced in 1951 as a measure to prevent erosion and land degradation. The government used the measure to encourage the public to plant trees to fulfill this goal (Nawir et al., 2008). However, in 1996, the RPL's purpose shifted to efficient utilization of home-yards, which would provide alternative land for food production and help meet household food needs. Furthermore, KRPL was launched in the early 2010s to improve food intake through diversification in varieties of consumed food and nutrition by those engaging in the KRPL program. It was also an attempt to empower female household members. During the 2011-2015 period, the KRPL program was implemented in 12,000 communities in 33 states in Indonesia (Food Security Agency, 2013).

The KRPL program is carried out by groups of women with mentoring by extension workers. At any given site, KRPL implementation entails (1) meeting food needs and diversifying food and nutrient intake at the household level, (2) conservation of crops, (3) management of nurseries, and (4) improving welfare by increasing income. Furthermore, a participatory approach is adopted by attempts to establish a clear decision-making process within the group, improve access to information beyond technical advice and services from the government, strengthen inter/intra-group cooperation, enhance harmony within local communities, and nurture leadership among participants.

To support KRPL, the government helps establish nurseries with a view to providing crop seedlings to be grown through KRPL activities. The existence of a nursery overcomes difficulties posed in growing seeds and increases family income through sales of seeds to these nurseries. To improve the quality of human resources, especially for female members of households, the government conducts training activities regarding crop production with plastic container pots, nursery management, composting household waste, and utilization of herbs as pesticides. Those activities are also financed by KRPL participants and NGOs in addition to central and local governments.

\section{Methodology and Data}

Our study area is Banten State, which is located in western Java. It lies next to DKI Jakarta State, which is the national capital. Banten has four regencies; Pandeglang, Lebak, Tangerang, and Serang, and four autonomous cities; Tangerang City, Cilegon City, Serang City, and Tangerang Selatan City. The population of Bantan is 11,955,243 people (cited from homepage of Badan Pusat Statistik) and covers a land area of about 9,663 square kilometers. The major agricultural commodity is rice.

The number of KRPL activities in Banten has continuously increased since 2011. Although the KRPL program was carried out only in one regency, Serang, in 2011, this increased to activities in 25 areas across four regencies and four cities in 2017. The number of KRPL participants in Banten is estimated to be approximately 530 women by the Banten Assessment Institute for Agricultural Technology. This study covers all three KRPL administrative zones in Banten, which are as follows: 
- Zone 1: Serang regency, Cilegon City, and Serang City;

- Zone 2: Pandeglang regency and Lebak regency; and,

- Zone 3: Tangerang regency, Tangerang City, and South Tangerang City.

All of the regencies, along with Cilegon City and Serang City are selected as study areas (Note 2). Structured interviews were conducted with 230 women participants in the KRPL program. The selection of the interviewees was done through a multi-stage selection procedure involving purposive and simple random sampling techniques. The interviews cover socioeconomic status of the respondents, motivation for participating in the KRPL program, and varieties and production amounts of vegetables grown with plastic pots.

As for socioeconomic characteristics of the 230 female respondents (Note 3), Table 1 shows that $52.6 \%$ are between 31 and 40 years old, 55.2\% finished senior high school, and $84.3 \%$ own less than $36 \mathrm{~m}^{2}$ of land (except for land occupied by a building). According to several agricultural extension offiers in charge of KRPL, the above-mentioned socioeconomic characteristics suggest that our sample seems to well represent the population. Most of the households have a yard only in front of their house, since the study areas are located in densely populated urban and suburban areas.

In this study, in order to evaluate the effects on household income arising from participating in the KRPL program, we estimate imputed value plus sales turnover from pot farming by multiplying the number of pots, yield per pot, number of harvests, and average retail price for all vegetable products together. Since free organic composite materials are widely used instead of chemical fertilizer and plastic pots are provided by the local government free of charge or at a reasonably low price of approximately Rp 1,000 per pot (1 USD is approximately equal to $\mathrm{Rp} 13,000$ ), the low amount of possibly incurred costs are ignored in this study.

To identify the factors determining the extent to which a participant is more actively involved in the KRPL program, we estimate the following equations by Ordinary Least Squares (OLS). The number of plastic container pots and number of varieties of vegetables that a participant plants are used as proxy dependent variables of the extent of participation in the KRPL program. Independent variables, selected based upon several previous studies regarding UPA and suggestions by agricultural extension workers in charge of KRPL, are a dummy for age [below 40 (reference category), 40s, and 50s], a dummy for education level [elementary school (reference category), junior high school, senior high school, and college/university], a dummy for motivation for

Table 1. Socioeconomic characteristics of KRPL participants in the study area

\begin{tabular}{lcc}
\hline Characteristics of participants & $\begin{array}{c}\text { Frequency } \\
\text { (persons) }\end{array}$ & $\begin{array}{c}\text { Percentage } \\
\text { (percent) }\end{array}$ \\
\hline Age (years) & 3 & 1.3 \\
$<20$ & 62 & 27.0 \\
$21-30$ & 121 & 52.6 \\
$31-40$ & 36 & 15.7 \\
$41-50$ & 8 & 3.5 \\
$>50$ & $39.3(7.8)$ & \\
Mean (s.d.) & & 9.1 \\
Level of education & 21 & 31.3 \\
Elementary school & 72 & 55.2 \\
Junior high school & 127 & 4.4 \\
Senior high school & 10 & 84.3 \\
College/University & & 15.7 \\
Land yard size & 194 & 100 \\
$<36 \mathrm{~m}^{2}$ & 36 & \\
$>36 \mathrm{~m}^{2}$ & 230 & \\
Total & & \\
\hline
\end{tabular}

Note. Field survey, November 2014. 
participating in the KRPL program [utilize home-yard more effectively (reference category), increase income, get fresh vegetables, enjoy gardening and/or planting vegetables, and follow friends/neighbors/relatives participating in the KRPL program], a dummy for usage of products [for self-consumption (reference category), for sale, and for giving to friends/neighbors/relatives free of charge], and a dummy of resident region [Cilegon City (reference category), Lebak district, Pandeglang district, Serang City, Serang district, and Tangerang district].

\section{Results and discussion}

We first provide an overview of vegetable farming under the KRPL program as determined from our interview survey data. Varieties of vegetables grown by female participants are shown in Table 2. Almost all participants

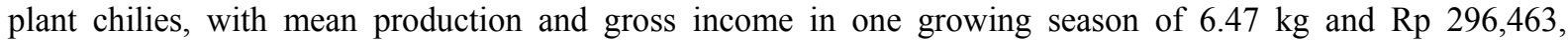
respectively. Many interviewees pointed out that chilies are consumed in a large amount as one of the most important spices in Indonesian dishes and its market prices remain high due to robust demand along with the rapid population growth and stagnant chili production in recent several years. Vegetables grown by more than half of participants are celery (68.7\%), kai lan (Chinese cabbage) (61.3\%), mustard (61.3\%), and tomatoes.

The imputed value plus sales turnover from pot farming in one growing season for 230 households is, on average, Rp 374,534 compared to Rp 2,919,152 total monthly household income excluding pot farming income. It is common for participants to grow several crops of vegetables in the same pots over the course of a year, depending on climate conditions, labor availability, and personal enthusiasm for pot farming. In case of chilies, the growing season is 3-4 months; therefore, a participant can harvest chilies at least twice a year. Assuming that a participant plants the same vegetables in the same number of pots and harvests the same volumes of vegetables twice a year, the proportion of pot farming to the annual household income is estimated to be $2.1 \%$ $[=(\mathrm{Rp} 374,534 \times 2$ times $) /(\mathrm{Rp} 2,919152 \times 12$ months $)]$. Therefore, participating in the KRPL program results in cutting back on expenditure on fresh vegetables and/or increasing household income to a certain extent, suggesting that promoting the KRPL program in urban and peri-urban areas is one of the possible policy options for an urban and peri-urban community development program.

Here, it should also be noted that the total amounts of vegetable production (excluding chilies and mustard) and spices (chilies and mustard) in one growing season are $7.99 \mathrm{~kg}$ and $8.71 \mathrm{~kg}$, respectively. According to the FAO's FAOSTAT database, annual per capita supply of vegetables (beans, peas, pulses, tomatoes, onions, and other vegetables) and spices (pepper, pimento, cloves, and other spices) are $41.46 \mathrm{~kg}$ and $1.41 \mathrm{~kg}$, respectively. Assuming that a participant plants the same vegetables in the same number of pots and harvests the same volume of vegetables twice a year, pot farming accounts for approximately $9.6 \%$ [ $=(7.99 \mathrm{~kg} \times 2$ times $) /(41.46 \mathrm{~kg} \times 4$

Table 2. Overview of pot farming 230 female participants

\begin{tabular}{lcccc}
\hline Variety of Vegetables & $\begin{array}{c}\text { Number of } \\
\text { participants } \\
\text { planting } \\
\text { (persons) }\end{array}$ & $\begin{array}{c}\text { Percentage } \\
\text { (percent) }\end{array}$ & $\begin{array}{c}\text { Production in one } \\
\text { growing season } \\
(\mathrm{kg})\end{array}$ & $\begin{array}{c}\text { Gross income in } \\
\text { one growing season } \\
\text { (Rp) }\end{array}$ \\
\hline Chili & 228 & 99.1 & 6.47 & 296,463 \\
Eggplant & 140 & 60.9 & 1.72 & 9,971 \\
Lettuce & 67 & 29.1 & 0.14 & 3,352 \\
Cauliflower & 88 & 38.3 & 0.40 & 5,573 \\
Cabbage & 37 & 16.1 & 0.27 & 1,644 \\
Celery & 158 & 68.7 & 0.58 & 6,326 \\
Tomato & 120 & 52.2 & 3.47 & 20,151 \\
Spinach & 25 & 10.9 & 0.10 & 575 \\
Kai lan & 141 & 61.3 & 0.83 & 12,453 \\
Long bean & 23 & 9.2 & 0.21 & 1,546 \\
Packoy & 51 & 22.2 & 0.27 & 2,144 \\
Mustard & 141 & 61.3 & 2.24 & 14,336 \\
\hline
\end{tabular}

Note. Field survey, November 2014. 
persons)] of annual vegetable consumption for a family of four members. The amount of chili and mustard production is, on average, well over a family's annual consumption, suggesting a large proportion of spices produced are sold to supplement income.

The numbers of pots and vegetable varieties planted by participants are shown in Table 3 . The majority of the respondents (31.3\%) have 11 to 20 pots and $14.3 \%$ of participants have more than 30 pots. The mean number of pots used for farming is 13.8 . The mean number of vegetable varieties planted is 5.3 , and $15.7 \%$ of participants plant more than eight varieties of vegetables in one growing season. On the other hand, only $4.8 \%$ of participants plant one or two varieties, suggesting a majority of participants grow many varieties of vegetables and pot farming contributes to consumption diversification.

Tables 4 and 5 provide the estimation results of the OLS models regarding the numbers of pots used and vegetable varieties grown under the KRPL program. The results for the number of plastic pots used show that some independent variables are statistically significant at the $1 \%$ and $5 \%$ levels. The following coefficients are significant: dummy for motivation for participating in the KRPL program (liking gardening and/or planting vegetables, and following friends/neighbors/relatives participating in the KRPL program), dummy for usage of products (for sale and for giving friends/neighbors/relatives free of charge), and dummy of resident region (Lebak district, Pandeglang district, Serang City, Serang district, and Tangerang district). Given that the other variables are constant, a participant who likes gardening and/or planting vegetables tends to use 16.2 more pots than a counterpart whose motivation for participating in the KRPL program is more effective utilization of her home-yard. On the other hand, a participant who only follows friends/neighbors/relatives participating in the KRPL program utilizes 9.0 fewer pots than a counterpart, suggesting that a passive motivation for participating

Table 3. Distribution numbers of pots and vegetables

\begin{tabular}{lrr}
\hline Variable & Frequency & Percentage \\
\hline Number of pots used & 63 & 27.4 \\
$<10$ & 72 & 31.3 \\
$11-20$ & 62 & 27.0 \\
$21-30$ & 18 & 7.8 \\
$31-40$ & 10 & 4.4 \\
$41-50$ & 4 & 1.7 \\
$51-60$ & 1 & 0.4 \\
$>60$ & 230 & 100.0 \\
Total & & 13.8 \\
Mean & & \\
Number of vegetable varieties planted & 2 & 0.9 \\
1 & 9 & 3.9 \\
2 & 32 & 13.9 \\
3 & 51 & 22.2 \\
4 & 38 & 16.5 \\
5 & 40 & 17.4 \\
6 & 22 & 9.6 \\
7 & 14 & 6.1 \\
8 & 17 & 7.4 \\
9 & 5 & 2.2 \\
10 & 230 & 100.0 \\
Total & & 5.3 \\
\hline Mean & &
\end{tabular}

Note. Field survey, November 2014. 
in the program leads to less enthusiasm about expanding her pot farm size. Compared to a participant living in Cilegon City, which is located in the far north-west part of the Banten State, participants living in Lebak district and Pandeglang district, both of which are located in the backward southern parts of the state, are likely to have 8.1 and 11.6 fewer pots. On the contrary, participants residing in more developed northern parts of the state such as Serang City, Serang district, and Tengerang district, all of which are directly connected to the capital city by the Jakarta-Merak toll road, tend to have 8.7, 5.8, and 4.8 more pots than their counterparts in Cilegon City.

As for the number of vegetable varieties grown under the KRPL program, the dummy for motivation for participating in the KRPL program (liking gardening and/or planting vegetables, and following friends/neighbors/relatives participating in the KRPL program) and dummy of resident region (Lebak district, Pandeglang district, Serang City, and Tangerang district) are significant. Similar to the findings for the case of numbers of pot used as shown in Table 4, with the other variables being constant, a participant who likes gardening and/or planting vegetables tends to grow 0.9 more varieties than her counterpart whose motivation for participating in the KRPL program is more effective utilization of her home-yard. On the other hand, a participant who simply is following friends/neighbors/relatives participating in the KRPL program plants 1.7

Table 4. Estimation results of the number of pots used (OLS)

\begin{tabular}{|c|c|c|c|}
\hline & Coefficient & S.E. & $\mathrm{P}>\mathrm{t}$ \\
\hline \multicolumn{4}{|l|}{ Dummy for age } \\
\hline \multicolumn{4}{|l|}{ Below 40 (reference) } \\
\hline $40 \mathrm{~s}$ & -0.460 & 1.174 & 0.695 \\
\hline $50 \mathrm{~s}$ & -1.455 & 1.840 & 0.430 \\
\hline \multicolumn{4}{|l|}{ Dummy for education level } \\
\hline \multicolumn{4}{|l|}{ Elementary school (reference) } \\
\hline Junior high school & -1.425 & 2.159 & 0.510 \\
\hline Senior high school & -2.323 & 2.439 & 0.342 \\
\hline College/university & -3.641 & 3.503 & 0.300 \\
\hline \multicolumn{4}{|c|}{ Dummy for motivation for participating in the KRPL program } \\
\hline \multicolumn{4}{|l|}{ Utilize home-yard more effectively (reference) } \\
\hline Increase income & -2.421 & 1.979 & 0.223 \\
\hline Get fresh vegetables & -0.545 & 1.144 & 0.634 \\
\hline Like gardening and/or planting vegetables & 16.202 & 2.057 & 0.000 \\
\hline Follow friends/neighbors/relatives & -9.046 & 3.157 & 0.005 \\
\hline \multicolumn{4}{|l|}{ Dummy for usage of products } \\
\hline \multicolumn{4}{|l|}{ For self-consumption (reference) } \\
\hline For giving friends/neighbors/relatives & 3.297 & 1.551 & 0.035 \\
\hline For sale & 10.436 & 1.487 & 0.000 \\
\hline \multicolumn{4}{|l|}{ Dummy of resident region } \\
\hline \multicolumn{4}{|l|}{ Cilegon City (reference) } \\
\hline Lebak district & -8.059 & 1.918 & 0.000 \\
\hline Pandeglang district & -11.629 & 1.910 & 0.000 \\
\hline Serang City & 8.684 & 1.929 & 0.000 \\
\hline Serang district & 5.824 & 1.793 & 0.001 \\
\hline Tangerang district & 4.822 & 1.968 & 0.015 \\
\hline Constant & 22.425 & 3.304 & 0.000 \\
\hline Adjusted R-squared & 0.623 & & \\
\hline
\end{tabular}


fewer pots than her counterpart, suggesting that a passive motivation for participating in the program leads to less enthusiasm about growing more varieties of vegetables. Compared to a participant living in Cilegon City, participants living in Lebak district and Pandeglang district are likely to grow 1.2 and 2.1 fewer vegetable varieties. On the contrary, participants staying in more developed northern parts of the state such as Serang City and Tengerang district tend to plant 2.5 more vegetable varieties than their counterparts in Cilegon City.

Table 5. Estimation results of the number of vegetable varieties grown (OLS)

\begin{tabular}{|c|c|c|c|}
\hline & Coefficient & S.E. & $\mathrm{P}>\mathrm{t}$ \\
\hline \multicolumn{4}{|l|}{ Dummy for age } \\
\hline \multicolumn{4}{|l|}{ Below 40 (reference) } \\
\hline $40 \mathrm{~s}$ & -0.032 & 0.171 & 0.851 \\
\hline $50 \mathrm{~s}$ & -0.060 & 0.268 & 0.825 \\
\hline \multicolumn{4}{|l|}{ Dummy for education level } \\
\hline \multicolumn{4}{|l|}{ Elementary school (reference) } \\
\hline Junior high school & -0.388 & 0.315 & 0.219 \\
\hline Senior high school & -0.523 & 0.356 & 0.143 \\
\hline College/university & -0.226 & 0.511 & 0.659 \\
\hline \multicolumn{4}{|c|}{ Dummy for motivation for participating in the KRPL program } \\
\hline \multicolumn{4}{|l|}{ Utilize home-yard more effectively (reference) } \\
\hline Increase income & -0.189 & 0.289 & 0.513 \\
\hline Get fresh vegetables & 0.186 & 0.167 & 0.266 \\
\hline Like gardening and/or planting vegetables & 0.924 & 0.300 & 0.002 \\
\hline Follow friends/neighbors/relatives & -1.734 & 0.460 & 0.000 \\
\hline \multicolumn{4}{|l|}{ Dummy for usage of products } \\
\hline \multicolumn{4}{|l|}{ For self-consumption (reference) } \\
\hline For giving friends/neighbors/relatives & 0.311 & 0.226 & 0.171 \\
\hline For sale & 0.438 & 0.217 & 0.045 \\
\hline \multicolumn{4}{|l|}{ Dummy of resident region } \\
\hline \multicolumn{4}{|l|}{ Cilegon City (reference) } \\
\hline Lebak district & -1.211 & 0.280 & 0.000 \\
\hline Pandeglang district & -2.092 & 0.278 & 0.000 \\
\hline Serang City & 2.526 & 0.281 & 0.000 \\
\hline Serang district & 0.237 & 0.261 & 0.365 \\
\hline Tangerang district & 2.484 & 0.287 & 0.000 \\
\hline Constant & 5.850 & 0.482 & 0.000 \\
\hline Adjusted R-squared & 0.712 & & \\
\hline
\end{tabular}

\section{Concluding Remarks}

This study aimed to (1) evaluate the effects of an urban and peri-urban agriculture program called KRPL on participants' household income and (2) identify factors affecting the extent to which a participant is actively involved in the program. Many varieties of fresh vegetables, such as chilies, celery, mustard, kai lan (Chinese broccoli), eggplants, tomatoes, cauliflower, lettuce, packoy (Chinese cabbage), cabbage, long beans, and spinach, are harvested from plastic pots, suggesting the program contributes to dietary diversification. In addition, imputed value plus sales turnover from pot farming in one growing season is, on average, Rp 374,534, compared to a Rp 2,919,152 total household income excluding pot farming income; therefore, participating in the KRPL 
program results in cutting back on expenditure on fresh vegetables and/or increasing household income to a certain extent. The estimation results of the regression model using the interview survey data indicate that a KRPL participant who has a larger number of pots and/or grows more varieties of vegetables tends to exhibit the following characteristics: (1) she likes gardening and/or spending time in nature, (2) she is not motivated by a passive reason for participating in the KRPL program, (3) she grows vegetables for the purpose of selling them, (4) the largest proportion of products is sold to someone or given to her friends/neighbors/relatives, and (5) she resides in the more developed northern part of Banten, which is directly connected to the capital city by the Jakarta-Merak toll road. Several personal attributes such as age and education level are not significant.

This study has also shown that participating in the KRPL program increases household disposable income through sales of products and/or reduction of consumption expenditure on vegetables, and improves household food and nutrition security to a certain extent. Additionally, the fact that all participants of the KRPL program are female should not be overlooked on the grounds that participating in the program is expected to strengthen social networks among women at the community level and improve female autonomy within households. Therefore, it is suggested that promoting the KRPL program in urban and peri-urban areas is one of the possible policy options for an urban and peri-urban community development program in developing countries.

Pot farming under the KRPL program faces several problems, such as pest and diseases, availability of seeds and seedlings, time constraints on farming, and lack of farming skills. According to the respondents, pests and diseases are rated as the biggest problem. The most problematic pests as revealed by the interviews, are Bemisia tabaci, Spodoptera litura, and rats, and the predominant disease is Fusarium oxysporum. The disease damages home-yard farming, especially chili plants. Respondents exhibit a lack of skills in farming. While the government provides training, the majority of female participants did not have experience in farming before they joined the KRPL program. An effective agricultural extension service should be provided to prevent participants from losing some portions of their vegetables to pests or diseases.

\section{References}

Ashebir, D., Pasquini, M., \& Bihon, W. (2007). Urban Agriculture in Mekelle, Tigray State, Ethiopia: Principal Characteristics, Opportunities and Constraints for Further Research and Development, Cities, 24(3), 218-228. http://dx.doi.org/10.1016/j.cities.2007.01.008

Bandara, J. S., \& Cai, Y. (2014). The Impact of Climate Change on Food Crop Productivity, Food Prices and Food Security in South Asia, Economic Analysis and Policy, 44(4), 451-465, http://dx.doi.org/10.1016/j.eap.2014.09.005

FAO (Food and Agriculture Organization of the United Nations). FAOSTAT: Food Balance Sheets. Rome: FAO. Retrieved March 30, 2017 from http://www.fao.org/faostat/en

FAO (2011). The Place of Urban and Peri-Urban Agriculture (UPA) in National Food Security Programmes. Rome: Technical Cooperation Department, FAO.

Food Security Agency (2013). Pedoman Percepatan Penganekaragaman Konsumsi Pangan. Jakarta: Indonesian Agriculture Ministry.

Freeman, D. B. (1991). A City of Farmers: Informal Urban Agriculture in the Open Spaces of Nairobi, Kenya. Toronto: McGill Queen's University Press.

Giovannucci, D., Scherr, S., Nierenberg, D, Hebebrand, C., Shapiro, J., Milder, J., \& Wheeler, K (2012). Food and Agriculture: the Future of Sustainability. A Strategic Input to the Sustainable Development in the 21st Century (SD21) Project. New York: United Nations Department of Economic and Social Affairs, Division for Sustainable Development.

Haryanto, W., \& Warsana (2014). Kawasan Rumah Pangan Lestari: Pekarangan untuk Diversifikasi Pangan. Jakarta: IAARD Press.

Hermawan, A., Bambang, S., Pramono, J., Yulianto, \& Indrie, A. (2014). Kawasan Rumah Pangan Lestari : Pekarangan untuk Diversifikasi Pangan. Jakarta: IAARD Press.

Iqbal, M. \& Sumaryanto (2007). Strategy to Control the Function of Converted Land is Focused on the Community Participation, Agricultural Policy Analysis, 5(2), 167-182.

Maxwell, D.G. (1995). Alternative Food Security Strategy: A Household Analysis of Urban Agriculture in Kampala, World Development, 23(10), 1669-1681. https://doi.org/10.1016/0305-750X(95)00073-L

Maxwell, D.G., Levin, C., \& Csete. J. (1998). Does Urban Agriculture Help Prevent Malnutrition? Evidence 
from Kampala, Food Policy, 23(5), 411-424. http://dx.doi.org/10.1016/S0306-9192(98)00047-5

Maxwell, D.G., \& Zziwa, S. (1992). Urban Farming in Africa: The Case of Kampala, Uganda, Nairobi: ACTS Press.

Meskhia, I. E. (2016). Food Security Problems in Post-Soviet Georgia. Annals of Agrarian Science, 14(2), 46-51, http://dx.doi.org/10.1016/j.aasci.2016.03.004

Ministry of Agriculture, Indonesia (2012). Pembangunan Model Kawasan Rumah Pangan Lestari, Jakarta.

Misra, A. K. (2014). Climate Change and Challenges of Water and Food Security. International Journal of Sustainable Built Environment, 3(1), 153-165. http://dx.doi.org/10.1016/j.ijsbe.2014.04.006

Mwangi, A. W. (1995). The Role of Urban Agriculture for Food Security in Low Income Areas in Nairobi, FNSP Report No. 54, Leiden: African Studies Centre.

Nawir, A. A., Murniati, \& Rumboko, L. (2008). Forest Rehabilitation in Indonesia: Where to After More Than Three decades?, Jakarta: Center for International Forestry Research.

Opitz, I., Berges, R., Piorr, A., \& Krikser, T. (2016). Contributing to Food Security in Urban Areas: Differences between Urban Agriculture and Peri-Urban Agriculture in the Global North, Agriculture and Human Values, 33(2), 341-358. http://dx.doi.org/10.1007/s10460-015-9610-2

Peters, C.J., Bills, N.L., Lembo, A.J., Wilkins, J.L., \& Fick, G.W. (2009). Mapping Potential Foodsheds in New York State: A Spatial Model for Evaluating the Capacity to Localize Food Production, Renewable Agriculture and Food Systems, 24(1), 72-84. https://doi.org/10.1017/S1742170508002457

Wong, N.H., Tan, P.Y., \& Chen, Y. (2007). Study of Thermal Performance of Extensive Rooftop Greenery Systems in the Tropical Climate. Building and Environment, 42(1), 25-54. https://doi.org/10.1016/j.buildenv.2005.07.030

Yusuf, S.A., Balogun, O.L., \& Falegbe, O.E. (2015). Effect of Urban Household Farming on Food Security Status in Ibadan Metropolis, Oyo State, Nigeria. Journal of Agricultural Sciences, 60(1), 61-75, http://dx.doi.org/10.2298/JAS1501061Y

\section{Notes}

Note 1. UPA can also prevent from increasing urban temperatures (Wong et al., 2007) and curbing greenhouse emissions by reducing the distance food travels (Peters et al., 2009).

Note 2. Tangerang city and South Tangerang city are excluded because KRPL practice is less popular or smaller in scale in these areas.

Note 3. Since most participants are female and male participants are rare, all our interviewees are female.

\section{Copyrights}

Copyright for this article is retained by the author(s), with first publication rights granted to the journal.

This is an open-access article distributed under the terms and conditions of the Creative Commons Attribution license (http://creativecommons.org/licenses/by/4.0/). 